OR-5

\title{
INVESTIGATION OF HYDRODYNAMIC PARAMETERS DISTRIBUTION IN HEAT EXCHANGE TUBES OF FALLING FILM EVAPORATOR
}

\author{
V. N. Gushshamova, A. P. Khomyakov, I. S. Kovalev, S.V.Mordanov \\ Ural Federal University of the first President of Russia B. N. Yeltsin, 19 Mira St., Yekaterinburg, \\ 620002, Russia \\ E-mail: 89126634949@yandex.ru
}

\begin{abstract}
Falling film evaporators have a high heat transfer rate with relatively small volumes of the device $[1,2,3]$. It is advisable to have information about changes in hydrodynamic parameters along the length of heat exchange tubes, when developing a falling film evaporator.

To obtain data on changes in the parameters of the vapor-liquid mixture along the length of the evaporator tube, we developed a mathematical model of the processes occurring in heat exchange tubes and a method for calculating the evaporator.

The research was carried out for the film evaporator with heat exchange tube (diameter of the tube $\emptyset 38 \times 2 \mathrm{~mm}$, length of the tube $\mathrm{L}=7 \mathrm{~m}$ ) with the following main technological parameters of the device:

1. Consumption of the initial solution: $50 \mathrm{l} / \mathrm{h}, 100 \mathrm{l} / \mathrm{h}, 150 \mathrm{l} / \mathrm{h}$;

2. Useful temperature difference: $15^{\circ} \mathrm{C}, 20^{\circ} \mathrm{C}, 25^{\circ} \mathrm{C}$;

3. The temperature of the initial solution: $60^{\circ} \mathrm{C}, 70^{\circ} \mathrm{C}, 80^{\circ} \mathrm{C}$;

4. The boiling point of the solution $70^{\circ} \mathrm{C}$.

The following data on changes in technological parameters along the length of heat exchange tubes are obtained: absolute pressure in the tube space, pressure losses along the length of the tube, mass flow rates of water and secondary steam in the tube space, and secondary steam velocities along the length of the tube.

We have studied the effect of the flow rate and temperature of the initial solution, the useful temperature difference on the distribution of hydrodynamic parameters along the length of the heat exchange tube of the evaporator.

The obtained data on the distribution of hydrodynamic parameters were used in the development of film-type evaporators.

\section{References}

1. Evaporation of heat sensitive materials / J. G. Moore, W. E. Hesler // Chemical Engineering Progress. - 1963. Vol. 59. - P. 87-92.

2. Heat transfer in falling-film long-tube vertical evaporators / J. R. Sinek, E. H. Young // Chemical Engineering Progress. 1962. Vol. 58 - P. 74-80.

3. Modeling and simulation of an industrial falling film evaporator for alumina production / X. Wang, P. Xiong, K. Suna, Y. Xie, C. Yang // Chemical Engineering Research and Design. - 2019. Vol. 154. - P. 303-315.
\end{abstract}

